\title{
Hommage à Georges Duby, membre de l'Académie française et professeur au Collège de France
}

En partenariat avec les revues Religions \& Histoire et Le monde de la Bible

\section{OpenEdition}

\section{Journals}

Édition électronique

URL : https://journals.openedition.org/cem/4153

DOI : $10.4000 /$ cem. 4153

ISSN : 1954-3093

Éditeur

Centre d'études médiévales Saint-Germain d'Auxerre

Référence électronique

"Hommage à Georges Duby, membre de l'Académie française et professeur au Collège de France », Bulletin du centre d'études médiévales d'Auxerre / BUCEMA [En ligne], Hors-série n 1 | 2008, mis en ligne le 28 janvier 2008, consulté le 04 mars 2023. URL : http://journals.openedition.org/cem/4153 ; DOI : https://doi.org/10.4000/cem.4153

Ce document a été généré automatiquement le 4 mars 2023.

\section{(c) (†) 8 (2)}

Creative Commons - Attribution - Pas d'Utilisation Commerciale - Partage dans les Mêmes Conditions 4.0 International - CC BY-NC-SA 4.0

https://creativecommons.org/licenses/by-nc-sa/4.0/ 


\section{Hommage à Georges Duby, membre de l'Académie française et professeur au Collège de France}

En partenariat avec les revues Religions \& Histoire et Le monde de la Bible



1 À l'occasion du vingtième anniversaire de sa création (1986-2006), le Centre d'études médiévales d'Auxerre a tenu à honorer la mémoire de son fondateur, Georges Duby, décédé exactement dix ans après la signature de la première convention liant le CNRS et la Ville d'Auxerre (janvier 1986/décembre 1996). Désireux de tirer un bilan dynamique d'une œuvre encore extrêmement féconde, les participants à la journée d'hommage du samedi 20 septembre se sont efforcés de rappeler la cohérence d'ensemble des écrits de G. Duby (D. Iogna-Prat), tout en revenant sur trois tournants de sa recherche sur le "féodalisme » : 1/ sa thèse sur le Mâconnais (F. Bougard) ; 2 / la question de la "révolution féodale» (F. Mazel); 3/la part de la ruralité et de l'économique dans le système féodal (L. Feller). La contribution de D. Iogna-Prat, tirée du dossier d'introduction ("L'atelier de l'historien ») à la réédition de la première partie de l'œuvre de G. Duby dans Qu'est-ce que la société féodale? (Paris, Flammarion, 2002 [« Mille \& une pages »], p. VII-XXXIII) n'est pas reprise ici. Une version "papier » de celle de F. Mazel doit être publiée dans une prochaine livraison de Médiévales (2008).

- Georges Duby et les Études d'histoire rurale, par Laurent Feller 
- Pouvoir aristocratique et Église aux $\mathrm{X}^{\mathrm{e}}-\mathrm{XI}^{\mathrm{e}}$ siècles. Retour sur la « révolution féodale » dans l'œuvre de Georges Duby, par Florian Mazel

- Genèse et réception du Mâconnais de Georges Duby, par François Bougard 